International Journal of Scholarly Papers for Media and Communications

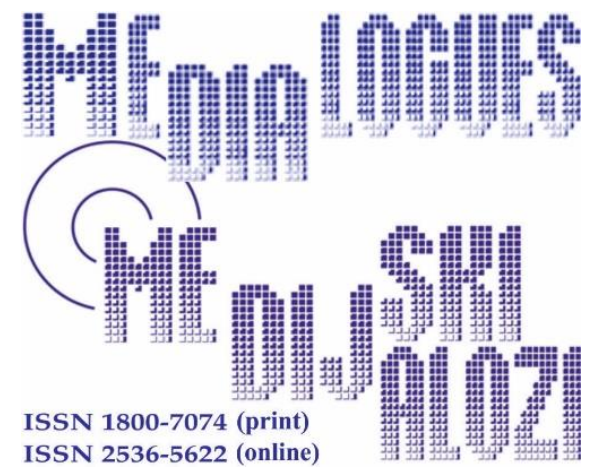

Betcheva, R. (2011), „Media Self Regulation and its Challenges”, Media Dialogues / Medijski dijalozi, Vol. 14, No. 4, pp. 67-71.

\title{
Media Self Regulation and its Challenges
}

\author{
RADKA BETCHEVA,
}

Head of Media Programme OSCE Mission to Montenegro

\begin{tabular}{|c|c|}
\hline $\boldsymbol{A} \boldsymbol{R} \boldsymbol{T} \boldsymbol{I} \boldsymbol{C L} \boldsymbol{E}$ & Received: January 17, 2021 / Revised from: March 17, 2021 \\
$\boldsymbol{I} \boldsymbol{N} \boldsymbol{F} \boldsymbol{O}$ & Accepted: May 03, 2021 / Available online: October 15, 2021 \\
\hline DOI & doi.org/10.14254/1800-7074/14-4/5 \\
\hline
\end{tabular}

\begin{abstract}
The Article argues, that media self-regulation is a democratic phenomenon, which requires a proper legislative media framework providing for freedom of media and freedom of expression. Media self-regulation protects the audience from unethical media reporting and safeguards professional standards. Solid professional standards make media stronger and more resilient to pressure from powerful political and/or economic interests. Media self-regulation supports also media economic interests helping them to gain the trust of the audience from one hand and avoid expensive court cases on the other hand. In the time of the economic crisis media selfregulation is challenged under the pressure for survival and the chaise for profit. This makes media much more susceptible to sensationalism and violations of the Code of ethics
\end{abstract}


KEYWORDS: Media Self-Regulation, Media Accountability, Professional Standards, Communications.

\section{CONDITIONS}

Media self-regulation is a democratic phenomenon. It requires organization of a state in a way, which promotes freedom of expression and freedom of media. Selfregulation in the media could be developed if there is a respective legislative media framework in place, which guarantees freedom of expression. Normally each democratic state provides for freedom of expression in its constitution and regulates this fundamental human right in a set of media laws.

However, freedom of expression is not an absolute freedom. It has its limits. As it is stipulated in the Convention for Protection of Human Rights and Fundamental Freedoms Article 10 "The exercise of these freedoms, since it carries with it duties and responsibilities, may be subject to such formalities, conditions, restrictions or penalties as are prescribed by law and are necessary in a democratic society, in the interests of national security, territorial integrity or public safety, for the prevention of disorder or crime, for the protection of health or morals, for the protection of the reputation or rights of others, for preventing the disclosure of information received in confidence, or for maintaining the authority and impartiality of the judiciary".

Balancing between the right of freedom of expression and other human rights and interests, such as for instance the right to privacy, the right to presumption of innocence, the right to protection of minors, etc. requires observation of the law and establishment of Code of Ethics and respective bodies, which ensure their implementation in practice.

\section{THE GOALS OF MEDIA SELF REGULATION}

Through establishment and adoption of Codes of Ethics the media set out their own professional standards and limits. In such a way the media self-regulation strengthens and safeguards professional standards. Media, which is professional and hold high standards gain the trust of their audience and respectively supports their own sustainability. Media self-regulation provides a mechanism for a constant analysis of media performance and compliance with professional standards, which constantly elevates the quality of media reporting. On the other hand solid professional standards make media stronger and more resilient to pressure from powerful political and/or economic interests. Thus the media self-regulation supports media freedom and independence of editorial policy and keeps away the state from interference in media through unnecessary regulation. 
When media manage to regulate themselves they send a positive message to the society that they are responsible and accountable in their work. On the other hand, the media accountability mechanism helps them solve complaints against journalists in amicable way avoiding expensive court cases.

Media self-regulation protects the interests of the audience from unethical reporting and violation of human rights.

\section{MEDIA INTERESTS IN SELF-REGULATION}

Media compete with each other to get the trust of the audience. Media selfregulation is a mechanism, which helps the achievement of this long-term goal and thus indirectly provides a strong economic incentive. If media lose the trust of the audience, it will lose this audience, and it would negatively impact the sell of their work.

Every media wants to keep a high professional image. If it breaches the Code of Ethics and the respective media self regulatory body decides that this is the case, the decision is published in all competitive media, which would gladly use the opportunity to fight their competitors.

The media in young democracies is highly protective to their rights stipulated by the Constitution and the law. Media self-regulation is a mechanism, which ensures for self-accountability of the profession to the society and keeps the state away from interference.

When complaints against media and journalists are solved amicably through the media self-regulation mechanism, the cases are not going to the Court and media outlets save money and time for expensive court procedures.

Media is well aware that if they do not regulate themselves they will be regulated by the state!

\section{MODELS FOR MEDIA SELF REGULATION}

The research on models of media self-regulatory mechanisms throughout the world shows that there is not one universal or single model of media self-regulation.

There are many systems for media self-regulation. Media self-regulation could be organized on a national or/and on a regional level. It could be completely decentralized and each media outlet could have its own accountability mechanism. France offers an example of decentralized model for media self-regulation operating on single media level. 
Media self-regulation could embrace print and electronic media or could be established only for print media. Australia, Canada and many countries throughout Europe have Press Councils for print media.

Some countries as Sweden have Media Ombudsman, which is an institution with a long tradition and credibility.

According to Prof. Claude Jean Bertrand, one of the best researchers of media accountability mechanisms in the world, the best model for media self regulation is the three party model, when the media self-regulation system includes representatives of the media industry, representatives of journalistic associations and lay members. In such way the media self-regulatory mechanism covers and protects all involved interests - the interests of those who sell the news, of those who create them, and those who consume them. Many of the media self-regulatory bodies in Europe have three partite models and include representation of the industry, lay membership, and journalists.

In some countries journalists have such strong professional organizations, which take full responsibility for the development of their profession and for eleva- ting the professional standards, that they do not allow other representation in the selfregulatory mechanism, except journalists. Swiss is a good example.

Interesting model for media self-regulation present some countries in Caucasus and Asia, in which the Councils for media ethics include lawyers, journalists and lay membership. Having in mind the heavy dilemmas, with which the councils everywhere in the world are struggling having to decide sometimes between two equal human rights, presence of lawyers in the councils could prove to be very helpful. On the other hand, the Courts when deciding on media cases could consider the decisions taken by the councils.

\section{CHALLENGES}

It seems that one of the biggest challenges in the time of the economic crisis is that the struggle for surviving or the chase for profit make media highly susceptible to sensations and violations of media ethics. The more the media breach the professional Code of Conduct, the more they irritate centers of economic and political powers and the more they irritate them, the more these centers bounce back and try to attack media freedom and to control them. This could perpetuate in a vicious circle, which could be broken with an effective work of a media self regulatory mechanism, which protects professional standards.

Why media self-regulation faces so many challenges nowadays? Could we talk about media ethics in one even more commercialized society? Those are questi- ons, which turn to be difficult even in developed countries. In the time of economic crisis, when budgets are cut everywhere, the quality of professional journalism is i- nevitably badly influenced. Editors in chief in established democracies complain, that 
facts are not checked, as they should have, and that financial restrictions negatively impact the quality of reporting. Crisis according to media gurus has especially negative impact on investigative journalism, which requires a serious research and bigger finances.

Media is an institution with its own history, development and mission. Its primary mandate is to inform and educate the society. It is highly influential. That's why it is called the fourth power. However, this is only one side of it. The other side is that the media are business establishments, which have to survive on the market as any other business and looking after profit as any other business. This is what sometimes drives them to make concessions with ethical standards and become susceptive to sensations.

These arguments are even exacerbated in the hungry, small, still developing and highly competitive media markets on the Balkans, where very often there is a lack of strong professional organizations and media faces even bigger challenges to observe ethical standards.

\section{BIBLIOGRAPHY}

The Media Self-Regulation Guidebook, All questions and answers, The OSCE Representative on Freedom of Media Miklos Haraszti

The Code of Ethics and media, The OSCE Mission in Montenegro

ECHR

Media Laws

Statutes of the Self Regulatory

Body Code of Ethics

Survey "Freedom and Responsibility": Guaranteeing of the Freedom of Speech through a Self Regulation of the Media, conducted as a part of a project "Towards free and independent media through a legislative reform and self regulation", ordered by the Institut fur Auslandsbeziehungen (IFA) and financed by the Federal Republic of Germany in the frame of the Stability Pact for South Eastern Europe

http://icie.zkm.de/research

$\mathrm{http} / / / \mathrm{www}$. tjonline.org/MAS-Press-Councils/ 